Tersedia online di: http://ejournal-balitbang.kkp.go.id/index.php/JP
e-mail:jurnalpari@gmail.com
JURNAL PARI
Volume 3 Nomor 1 Juli 2017
p-ISSN: 2502-0730
e-ISSN : 2549-0133

\title{
PENTINGNYA LITERASI INFORMASI DIGITAL BAGI PUSTAKAWAN DALAM MENDUKUNG KEGIATAN LITBANG
}

The Importance of Digital Information Literacy For Librarian in Supporting Reseacrh and Development

\author{
KETUT MASIANI \\ Balai Besar Riset Budidaya Laut dan Penyuluh Perikanan \\ Diterima tanggal : 2 Februari 2017 diterima setelah perbaikan : 24 Mei 2017 disetujui terbit : 30 Juni 2017
}

\begin{abstract}
ABSTRAK
Perkembangan teknologi informasi yang sangat pesat dewasa ini perlu diantisipasi oleh pustakawan untuk mendukung kegiatan penelitian di lingkungan lembaga induknya, khususnya di unit penelitian dan pengembangan (Litbang). Pemilihan dan pemberian informasi yang tepat dan akurat sangat diperlukan untuk kegiatan penelitian yang berkelanjutan, mulai dari penyusunan rencana sampai ke tahap evaluasi, pelaporan dan publikasi hasil kegiatan. Informasi merupakan faktor kunci dalam keberhasilan kegiatan litbang. Pustakawan yang memiliki kemampuan dalam literasi informasi akan mampu mengetahui kebutuhan pengguna secara tepat. Lokasi sumber informasi, cara memperoleh informasi, etika dalam memakai informasi, serta bagaimana mengelola informasi yang sudah didapatkan perlu diketahui oleh setiap pustakawan. Kemampuan literasi informasi tersebut sangat penting dan wajib dimiliki oleh seorang pustakawan guna mendukung kelancaran kegiatan litbang.
\end{abstract}

Kata kunci: Informasi dan teknologi, Literasi, Pustakawan, Informasi digital, Penelitian dan pengembangan

\section{ABSTRACT}

The rapid development of information technology today needs to be anticipated by librarians to support research activities within their parent institutions, particularly in research and development units $(R \& D)$. The selection and provision of appropriate and accurate information is essential for ongoing research activities, from preparing and evaluating the plans, reporting and publicating the results of activities. Information is a key factor in the success of $R \& D$ activities. Librarians who have ability in information literacy will be able to know the needs of users appropriately. How to locate the information resources obtain the information, use it and manage it correctly, should be known by every librarian. Information literacy is very important and must be owned by a librarian to support the continuity of $R \& D$ activities.

Keywords: Information and technology, Literacy, Librarian, Digital Information, Research and development

\footnotetext{
Korespondensi Penulis :

Br. Gondol. Desa Penyabangan, Kec.Gerokgak, Kab.

Buleleng, PO.BOX 140 Singaraja-Bali 81155

Email: ktmasiani@gmail.com
} 


\section{PENDAHULUAN}

Teknologi informasi (TI) dewasa ini telah berkembang dengan sangatpesat. Halinimenandakan bahwa banyak informasi yang telah dihasilkan oleh para pakar (information overload). Informasi ini tentunya harus dapat dikelola dengan baik oleh pustakawan agar dapat dimanfaakan secara optimal oleh pengguna. Banyaknya informasi yang tersedia dan mudah diperoleh tentu sangat bermanfaat bagi pencari informasi. Namun demikian informasi yang tidak diseleksi akan memberikan 2 arti, bermanfaat dan tidak bermanfaat. Bermanfaat jika informasi yang ada telah melalui proses pengolahan literatur, direview, dan mudah diakses. Tidak bermanfaat jika informasi yang ada tanpa melalui proses pengolahan dan review oleh para pakar dibidangnya. Perilaku perolehan informasi oleh pengguna perlu dipahami oleh pustakawan dan para ahli dibidangnya. Banyak yang menganggap penggunaan informasi yang dibutuhkan pengguna melalui perilaku copy, cut and paste merupakan hal yang biasa dan tidak disadarinya bahwa informasi yang diperoleh ini perlu dibaca ulang untuk memastikan keakuratan dan kebenarannya.

Information literacy (IL) berasal dari kata literacy dan information. Literacy menurut arti katanya dalam bahasa Inggris mengandung makna huruf, melek huruf dan yang berkaitan dengan kegiatan membaca dan menulis (Latuputty, 2013). Di Eropa, pengenalan tentang literasi informasi umumnya dimulai dari sektor pendidikan dan perpustakaan (Virkus, 2003). Literasi informasi mencakup seperangkat keterampilan untuk memecahkan masalah ataupun untuk membuat keputusan, baik untuk kepentingan akademisi ataupun pribadi, melalui proses pencarian, penemuan dan pemanfaatan informasi dari beragam sumber serta mengkomunikasikan pengetahuan baru secara efisien, efektif dan beretika (George dalam Latuputty, 2013).

Dengan kemampuan literasi informasi yang baik maka pustakawan akan mudah dalam memperoleh informasi yang tepat serta mampu mengelola atau mengolah informasi yang diperoleh sehingga informasi tersebut dapat dimanfaatkan secara optimal. Informasi yang diolah oleh pustakawan pada dasarnya adalah informasi literatur tercetak, sedangkan informasi digital jarang dikelola oleh pustakawan. Oleh sebab itu kajian tentang pengelolaan informasi digital menjadi sangat penting dilakukan.

\section{TINJAUAN LITERATUR}

Literasi informasi merupakan salah satu keterampilan yang harus dimiliki oleh pustakawan dalam menghadapi era digitalisasi. Dengan kemapuan literasi informasi maka akan dapat menemukan, mengevaluasi dan menggunakan informasi secara efektif. Dalam ALA disebutkan bahwa "To be information literate, a person must be able to recognize when information is needed and have the ability to locate, evaluate, and use effectively the needed information". Association of College And Research Library (2000) juga menyebutkan bahwa mereka yang memiliki literasi informasi adalah yang mampu menentukan dan sifat informasi, mengakses informasi secara efektif dan efisien, mengevaluasi informasi dan sumbernya secara kritis dan menggabungkan basis informasi dalam basis pengetahuan dan sistem nilainya, menggunakan informasi secara efektif dan memahami masalah ekonomi, hukum dan sosial dalam penggunaan dan akses informasi secara legal.

\section{Pustakawan dan literasi informasi}

Literasi informasi merupakan salah satu keterampilan dasar yang pada saat ini harus dimiliki oleh seorang pustakawan. Hal ini mengingat perkembangan teknologi informasi digital yang kian pesat dewasa ini. Pustakawan dituntut untuk dapat mengikuti dan memanfaatkan perkembangan teknologi untuk menunjang tugastugasnya. Pustakawan harus menjadi sumber informasi yang handal, dalam arti berkualitas dan menguasai perkembangan informasi dan teknologi. Kemampuan literasi informasi sangat membantu pustakawan dalam mengelola informasi secara efektif dan membantu meningkatkan kemampuan intelektualnya karena literasi informasi merupakan proses pembelajaran seumur hidup (life long learning) sehingga menjadi pustakawan yang melek informasi yaitu:

1. mengenali informasi yang dibutuhkan dan menentukan sifat dan cakupannya,

2. menemukan informasi secara efektif dan efisien,

3. mengevaluasi informasi dan proses pencarian informasi secara kritis,

4. mengelola informasi yang terkumpul atau didapatkan,

5. menggunakan informasi baru dan terdahulu untuk membuat konsep baru atau menciptakan 
pemahaman baru,menggunakan informasi dengan memahami nilai budaya, etika, ekonomi, hukum, dan sosial seputar penggunaan informasi. (Australian and New Zealand Information Framework ,2004)

\section{Memahami informasi yang dibutuhkan pemustaka}

Mengingat perpustakaan merupakan salah satu sumber informasi dalam kegiatan penelitian maka sudah selayaknya pustakawan sebagai pengelola perpustakaan mampu menyediakan berbagai kebutuhan infomasi yang up to date, dapat dipertanggung jawabkan serta mendukung kegiatan penelitian. Pustakawan juga harus mengetahui dan memiliki informasi-informasi yang dibutuhkan oleh pemustaka. Dengan mengetahui informasi yang dibutuhkan oleh pemustaka maka pustakawan akan dapat memberikan layanan informasi kepada pemustaka secara cepat dan tepat.

\section{Menentukan informasi yang tepat}

Seorang pustakawan dituntut untuk mampu memperoleh informasi dan melakukan evaluasi terhadap informasi yang diperolehnya sehingga informasi yang diberikan merupakan informasi yang benar, tepat dan dapat dipertanggung jawabkan. Informasi-informasi yang tidak objektif bisa berakibat fatal bagi pemustaka. Pustakawan harus mengidentifikasi dan menganalisis informasi yang diperoleh sehingga menjadi informasi yang objektif. Pustakawan harus pro aktif dalam mengevaluasi informasi-informasi terkini agar masyarakat tidak ketinggalan jaman. Puspa (2012) menyebutkan bahwa dengan membanjirnya informasi, seiring dengan perkembangan ilmu pengetahuan dan teknologi (iptek), pustakawan dituntut agar memiliki keterampilan literasi informasi sehingga dapat melakukan layanan yang maksimal kepada pemustaka.

\section{Mengelola informasi yang diperoleh}

Informasi-informasi yang telah diperoleh perlu dikelola secara tepat sehingga dapat dimanfaatkan secara optimal dan mudah ditelusuri oleh pengguna. Pada umumnya pemustaka bukan hanya mencari informasi yang digemarinya saja namun terkadang ada informasi yang dibutuhkan karena tuntutan pekerjaan atau profesinya. Pada dasarnya pemustaka tidak mempunyai cukup waktu untuk menelusuri informasi yang dibutuhkan, apalagi jika harus mengumpulkan informasi tersebut dari berbagai sumber. Mengingat akan pentingnya informasi tersebut maka perpustakaan sebagai salah satu pusat informasi sangatlah penting peranannya.Sebagai konsekuensinya maka perpustakaan dituntut mampu menyediakan informasi secara cepat, akurat, terkini dan dapat dipercaya. Hal ini akan dapat terlaksana dengan baik jika pustakawan sebagai brain power memiliki pengetahuan yang tinggi sehingga mampu mengolah dan menyediakan informasi sesuai dengan yang dibutuhkan pengguna.

Perpustakaan dapat berperan sebagai pusat informasi yang lengkap (one stop source for information). Pustakawan yang bekerja di perpustakaan dapat memberikan informasi bukan hanya dari koleksi yang dimiliki, namun juga dari sumber-sumber lain di luar perpustakaan. Untuk mencapai hal tersebut maka perpustakaan harus memiliki pustakawan yang handal dalam melakukan litarasi informasi. Selain koleksi buku, terbitan berkala, dan koleksi bahan cetak lainnya, koleksi digital juga sedang dikembangkan oleh banyak perpustakaan. Hal ini untuk memudahkan dalam proses pencarian informasi yang tersedia. Namun pustakawan sebagai motor utama dalam layanan perpustakaan, dituntut untuk lebih "melek" informasi, sehingga informasi yang dibutuhkan oleh pengguna dapat diberikan secara cepat dan akurat.

\section{METODE}

Kajian ini merupakan kajian literatur atas pentingnya literasi informasi bagi pustakawan, khususnya di Balai Besar Penelitian dan PengembanganBudidayaLaut, Singaraja-Bali. Data literatur primer dikumpulkan melalui penelusuran informasi dengan menggunakan kata kunci "literasi information atau information literacy, pustakawan atau librarian, dan perpustakaan khusus atau special libraries". Data hasil penelusuran kemudian dikelompokkan untuk mempermudahkan proses penjelasan atas permasalahan yang dihadapi hingga penjelasan dalam analisis deskriptif atas hasil yang diperoleh.

\section{HASIL DAN PEMBAHASAN}

Ketersediaan informasi merupakan salah satu faktor yang sangat penting dalam kegiatan litbang. Informasi yang akurat sangat diperlukan mulai dari 
penyusunan rencana hingga ke tahap evaluasi, pelaporan dan publikasi hasil kegiatan. Informasi merupakan faktor kunci dalam keberhasilan kegiatan litbang. Pustakawan dituntut untuk menjadi agen pertama yang mengetahui informasi terbaru. Oleh sebab itu pustakawan selalu dituntut keprofesionalismeannya dalam memenuhi kebutuhan pemustaka Keprofesionalismean pustakawan sangat membantu peneliti dalam melakukan kegiatan penelitian dan pengembangan. Informasi baru yang diberikan dapat meningkatkan pengetahuan dan ide-ide baru bagi peneliti untuk kegiatan penelitian dan pengembangan (litbang) selanjutnya.

Dalam kegiatan evaluasi terhadap publikasi hasil penelitian, informasi terbaru dari berbagai sumber sangatlah penting untuk dapat dipakai sebagai bahan referensi dan rujukan dalam analisis hasil penelitian. Di samping itu dengan mengetahui informasi dari berbagai sumber referensi dapat menghindarkan peneliti dari plagiasi terhadap karya tulis ilmiah (KTI) orang lain. Andriaty (2005) menyebutkan bahwa penulis/ peneliti dibidang pertanian belum banyak yang memanfaatkan jurnal elektronis untuk melengkapi hasil KTInya sehingga berpengaruh terhadap kemutakhiran informasi yang digunakan/disitir. Pernyataan tersebut menunjukkan bahwa literasi informasi menjadi penting dalam kegiatan litbang agar peneliti dapat memanfaatkan berbagai sumber referensi yang mutakhir/terkini sebagai bahan rujukan dalam penulisan $\mathrm{KTI}$. Oleh sebab itu literasi informasi ini sangatlah penting terutama jika dikaitkan dengan penelusuran literatur dalam penulisan KTI. Masiani dan Suratmi (2012) menegaskan bahwa berdasarkan analisis sitasi yang dilakukan terhadap KTI peneliti BBPPBLGondol, sebagian besar (63\%) KTI yang disitir peneliti adalah dalam bentuk jurnal, sedangkan artikel dari sumber lain seperti internet hanya sejumlah $4 \%$. Hal ini menunjukkan bahwa sangat sedikit sumber informasi terbaru lainnya yang dijadikan rujukan oleh peneliti dalam melengkapi KTI yang ditulisnya. Hal ini disebabkan juga oleh keterbatasan kemampuan peneliti dalam bahasa Inggris, selain rendahnya kemampuan mereka dalam menemukan informasi terbaru sebagai bahan rujukan. Pustakawan yang memiliki literasi informasi diharapkan dapat membantu pengguna dalam memenuhi kebutuhan akan informasi yang akurat sebagai sumber referensi dalam penulisan KTI.

Elly dan Nurhayati (2012) mengemukakan bahwa perpustakaan bisa memegang peranan yang penting bagi peneliti dan masyarakat apabila mampu merumuskan fungsinya selain sebagai pusat dokumentasi dan informasi juga sebagai pusat informasi ilmu pengetahuan dan teknologi (iptek) yang berorientasi pada pengguna jasa perpustakaan. Oleh sebab itu kemampuan literasi informasi bagi pustakawan menjadi sangat penting untuk menunjang kegiatan litbang. Hal ini dimaksudkan agar pustakawan benar-benar mampu mengetahui informasi yang dibutuhkan oleh pemustaka, memahami sumber-sumber informasi yang ada, mengetahui bagaimana cara menemukannya, memahami etika dalam memakai informasi, serta mampu bagaimana mengelola informasi yang sudah diperoleh.

Pada saat ini informasi merupakan komponen yang paling berpengaruh dalam keberhasilan mencapai tujuan litbang dan hasil karya ilmiah bagi para peneliti. Informasi-informasi yang akurat dan terkini akan dapat memberikan ide dan membantu kegiatan litbang serta dapat meningkatkan kualitas dan kuantitas hasil litbang. Perkembangan teknologi informasi yang sangat cepat, menuntut pustakawan dan perpustakaan untuk mengembangkan pengetahuan, keterampilan serta keahlian dalam bidang pengelolaan informasi, teknologi informasi serta literasi informasi. Menurut Dwiyanto (2007) pustakawan yang memiliki kemampuan dalam literasi informasi akan mampu:

1. Memahami bahwa informasi yang akurat dan tepat adalah dasar dari pengambilan keputusan.

2. Memahami kebutuhan akan informasi

3. Dapat mencari informasi yang diinginkan

4. Dapat menyusun pertanyaan berdasarkan informasi yang diinginkan

5. Dapat mengidentifikasi potensi sumbersumber informasi

6. Dapat membangun strategi pencarian informasi yang sukses

7. Dapat mengakses sumber informasi termasuk teknologi berbasis komputer dan teknologi lainnya

8. Dapat mengevaluasi informasi darimanapun sumbernya

9. Dapat mengorganisasikan informasi untuk kebutuhan praktis 
10. Dapat mengintegrasikan informasi yang diperoleh kedalam pengetahuan yang telah dimiliki

11. Dapat menggunakan informasi untuk berpikir kritis dan memecahkan masalah

12. Dapat menggunakan informasi secara etis dan legal

Kemampuan ini akan menjadikan pustakawan sebagai pintu terdepan sumber informasi yang muktahir dan menjadi tulang punggung peneliti sebagai sumber informasi.

\section{KESIMPULAN}

Kemampuan pustakawan dalam menyediakan informasi yang akurat dan terbarukan sangat dibutuhkan di perpustakaan lembaga litbang. Kemampuan dalam literasi informasi diperlukan agar informasi yang diberikan kepada pengguna benar-benar sesuai dengan kebutuhannya. Oleh sebab itu pustakawan BBPPBL harus mampu menyediakan dan mengelola informasi terbaru sehingga dapat memberikan layanan yang optimal kepada pemustaka serta mampu mendukung kegiatan litbang.

\section{DAFTAR PUSTAKA}

American Library Association. (1989) "Presidential Committee on Information Literacy : Final Report." www.ala.org/acrl/legalis.html. [Diakses 1 Desember 2015]

Andriaty, E. 2005. Pemanfaatan jurnal elektronis dan kemutakhiran informasi yang disitir dalam publikasi primer. Jurnal Perpustakaan Pertanian, 14 (2): 25-31

Association of college and research library. 2000. Information literacy competency standards for higher education: standards indicator performance indicators and outcomes. http:// www.ala/org/acrl/ilstandarlo.html. [Diakses 29/11/2015]
Australian and New Zealand Institute for Information Literacy. 2004. "Australian and New Zealand information literacy framework : principles, standards and practices" diunduh dari http://archive. caul.edu.au/info-literacy/ InfoLiteracyFramework.pdf. [Diakses 1 Desember 2015]

Dwiyanto, A.R. 2007 . Peran Perpustakaan Nasional RI dalam Pengembangan Literasi Informasi Sebagai Amanat Konstitusi . Visi Pustaka, 9(3). http://perpusnas.go.id/ MajalahOnlineAdd.aspx?id=77, [Diakses 1 Desember 2015]

Elly, A. dan S. Nurhayati. 2012. Peran perpustakaan dalam mendukung kegiatan penelitian. Prosiding Forum Kepustakawanan Lingkup Badan Penelitian dan Pengembangan Kelautan dan Perikanan. Bogor, 4-5 Oktober.

Latuputty, H. 2013. Cerdas di era informasi: Penerapan literasi informasi di sekolah untuk menciptakan pembelajar seumur hidup . http:// halatuputty.blogspot.co.id/2013/12/cerdas-diera-informasi-penerapan.html

Masiani. K. dan S. Suratmi. 2012. Analisis sitasi karya ilmiah peneliti BBPPBL Gondol Tahun 2011. Prosiding Forum Kepustakawanan Lingkup Badan Penelitian dan Pengembangan Kelautan dan Perikanan. Bogor, 4-5 Oktober.

Puspa, E. 2012. Urgensi keterampilan literasi informasi bagi pustakawan. Prosiding Forum Kepustakawanan Lingkup Badan Penelitian dan Pengembangan Kelautan dan Perikanan. Bogor, 4-5 Oktober.

Virkus, Sirje. 2003. Information Literacy in Europe: A literature review. Information Research, 8 (4). http://www.informationr.net [Diakses 15/03/2015] 